\title{
Vocabularies of Legitimation: Understanding Normative Killings
}

\author{
Mike Costelloe* and Alex Alvarez
}

Department of Criminology \& Criminal Justice, Northern Arizona University, Flagstaff, AZ 86011, USA

\begin{abstract}
This paper argues that while criminal forms of homicide have been the focus of extant research, little attention has been given to normative forms of killing. We argue that this omission is unfortunate and precludes a complete understanding of the contexts and consequences of killing. In this paper, we refer to three metaphors that are called into play when legitimizing certain forms of killing: Differential Life Value, Conservatism, and Justification. We call these "vocabularies of legitimation" and suggest that such normalization may serve to increase the prevalence of violence within society. Finally, we recommend some promising avenues for continuing research and possible directions for public policy.
\end{abstract}

Keywords: Violence, Killing, Normative, Legitimate.

\section{INTRODUCTION}

On February $26^{\text {th }} 2012$, a seventeen-year-old boy, armed with only a bag of candy and a soft drink, is shot and killed while walking home from a nearby convenience store. His killer, George Zimmerman, a 28-year-old neighborhood watch captain, followed and eventually approached (against a 911 dispatcher's instructions) the 17-year-old, Trayvon Martin, because he "looked suspicious." According to Zimmerman, the confrontation escalated after Zimmerman showed Martin that he had a gun, and the 17-year-old reportedly tried to take it from him. In the ensuing struggle, Zimmerman claims Martin gained the upperhand and began to slam his head against the pavement. Feeling threatened, the neighborhood watch captain shot and killed Martin, eventually claiming selfdefense.

What followed this tragedy and Zimmerman's subsequent acquittal was a firestorm of controversy that touched on a number of sensitive issues such as the role of race in America, the right to bear arms and "stand your ground" laws. Particularly polarizing was the debate as to whether Zimmerman's killing of Martin was justified. Some argued that Zimmerman was protecting his neighborhood and defending himself against a deadly threat, a threat he had no obligation to retreat from. Others, however, questioned the applicability of self defense and stand your ground principles when in fact Zimmerman by his own admission initiated contacted with, a young man who was by almost all accounts simply minding his own business and exercising his liberty to occupy a public street.

*Address correspondence to this author at the Department of Criminology \& Criminal Justice, Northern Arizona University, Flagstaff, AZ 86011, USA; Tel: (928) 523-7261; Fax: (928) 523-8011; E-mail: michael.costelloe@nau.edu
These are certainly difficult questions, but they clearly illustrate the contested nature of what is considered legitimate and illegitimate forms of killing. Cases such as this and others demonstrate a lack of consensus surrounding how different individuals and groups perceive and define some forms of killing. There is little doubt that most of us condemn killing out of anger or greed, but what may be less readily apparent is the existence of a realm of killing that is not so universally condemned, regardless of its legality. These might include such phenomena as the killing of an abusive partner or other victimizer by the victim, the death penalty and lynchings of the past. It is these forms of killing that is the focus of this paper. Specifically, we argue that where there is a lack of consensus about the acceptability of certain forms of killing greater efforts are necessary on the part of the perpetrator, whether it be an individual, group, or even the state, to justify or legitimate these acts. Further, we suggest that these efforts tend to have particular referents, which we call "vocabularies of legitimation." When such efforts are largely successful in gaining widespread acceptability, we call these killings "normative homicides." Because we feel that there is a compelling nexus between normative and nonnormative forms of homicides and violence, this paper more fully explores how some forms of killings are justified or legitimated while others are considered deviant.

The term normative homicide refers to those killings that fall within the bounds of acceptability and therefore may be considered legitimate. Ball-Rokeach (1980: 45) defines normative violence as "violence that is socially defined as legal, acceptable, or moral." It should be noted that normative or legitimate forms of killing are social definitions, not legal ones. The distinction is subtle yet important. Normative killings may in fact be against the law and technically subject to official 
sanctions even though many may approve and condone them. Conversely, it is also true that many legal killings are not necessarily legitimate, at least not in the eyes of many within the social audience. This is very clear when we examine the riots and protests that sometimes accompany police killings of minorities. Relying exclusively on a legalistic framework to explore the issue of acceptable killing limits the analysis to those specific types of killing defined in statutes as excusable or justifiable and is therefore much too narrow. The broader definitional framework of legitimacy, rather than legality, allows analysis of wider issues concerning definition and perception in regards to homicide and is therefore preferred.

While in this paper, the terms "normative homicide" and "normative violence" refer to acts that are legitimatized and thus viewed as acceptable, it is worth noting that others have ascribed a different meaning to these concepts. (i.e., Butler 1999; Butler 2004; Chambers 2007). For example, Samuel Chambers (2007: 43) uses normative violence to refer to the "violence of norms" rather than acts of violence that are "normative." In this sense, the "...norms themselves can do a certain violence to those bodies that would (necessarily) violate such norms" (2007: 44). In her book, Gender Trouble, Judith Butler (1999) suggests that acts such as "gay bashing" are not the violence of bigots, but is the inherent violence of gender norms. To avoid any confusion, then, we reiterate that we use these terms to address acts of violence that are legitimated or justified.

The study of normative killing is an important issue for several reasons. Illegitimate violence has long been considered an important social problem in the United States. Sensational offenses such as school shootings and high profile serial murder cases have kept media attention, and consequently public perceptions, focused on crime. Despite consistent decreases in many crime rate categories, it remains one of the top concerns for many Americans today.

While this concern typically focuses on criminal violence, the role of normative violence in perpetuating and exacerbating the problem must not be neglected since linkages appear to exist between different forms of violence (Turpin and Kurtz 1997). Evidence indicates that the legitimation of certain types of lethal violence may act as a stimulus to the perpetration of illegitimate forms of killing. Literature on the death penalty reveals that not only does the death penalty fail to deter (Archer 1983; Bailey 1982; Bailey and Peterson 1994;
Lempert 1983; Peterson and Bailey 1988; Peterson and Bailey 1991) but may well contribute to higher criminal homicide rates (Bowers 1984; Bowers and Pierce 1980; Cheatwood 1993; Shepherd 2005). The chief proponent of this argument William Bowers (1984: 274) argues that, "The lesson of the execution, then, may be to devalue life by the example of human sacrifice. Executions demonstrate that it is correct and appropriate to kill those who have gravely offended us." His "brutalization argument" as he terms it, asserts that the death penalty, through the desensitization of society to killing and devaluation of human life, increases tolerance toward lethal behavior and therefore increases the criminal homicide rate.

Such brutalization effects are not limited to state sanctioned activity such as the death penalty but also may extend to extra-legal killings that are nonetheless normative. Recently, Messner, Baler and Zevenbergen (2005) found empirical support to show that historic episodes of lynching in the South have had a lasting effect on current levels of homicides for blacks as well as for white on black homicides resulting from interpersonal conflicts. The authors suggest that for some blacks today's reliance on violence is a form of "self help" and a cultural adaption to past failures of the legal system to provide protection and justice against the threat of lynching. For whites, however, they argue violence results from a restricted brutalization effect linked to lynching. Nevertheless, for both whites and blacks, the current reliance on lethal violence is linked to instances of where individuals come to view it as a legitimate response to threats and conflict.

Arguing that involvement in wars also tends to legitimate the use of lethal force to resolve conflict and thereby increase the internal criminal homicide rate of a society (Archer 1984; Archer and Gartner 1976; Gartner 1990; Landau and Pfefferman 1988; Sidel and Wesley 1996), some have argued that just as the state has chosen to kill when in difficult circumstances, the citizens of that society will also be more likely to choose force when confronted with conflict. Others have more specifically argued that policies and practices of the state can serve to foster violence against subcultural groups, minorities, and women (Caulfield 1991; Tifft and Markham 1991). Additionally, like the death penalty, war undermines the "sensitiveness to human life" (Jane Addams (1915) as cited in Poe 2008: 35). That is, when justified, war and other forms of normative violence promote a 
desensitization to the physical and emotional pain of others (Poe 2008: 35).

Similarly, albeit in regards to typically nonlethal violence, Murray Straus (1994: 9) argues that the physical disciplining of children legitimates other forms of violence in interpersonal confrontations as physical punishment is inescapably an act of violence. He contends that the lesson learned is that violence is an acceptable means to an end and this behavior may well "spill over to other relationships in which hitting is not legal."

Though not without their detractors, these arguments strongly suggest that there exists a need to explore the phenomenon of normative killing in order to better understand the problem of killing in general. Important then, to this issue is an analysis of the ways in which killing is defined and perceived by those who perpetrate it and by the wider social audience that extends either approval or condemnation. We contend that through examination of commonalities found in different types of normative killings our understanding of violence and killing may be enhanced. Specifically, this paper identifies and discusses several elements that often serve to legitimate lethal violence and thus distinguish them from illegitimate killings. These "vocabularies of legitimation" act as important referents in defining whether certain killings are acceptable. We also explore various types of legitimate killing in the U.S. and illustrate the applicability of the referents for explaining perceptions of legitimacy. Finally, we conclude by suggesting some potentially fertile areas of future research.

\section{THEORIZING LEGITIMATION AND POWER}

While all killings share the same irreducible quality that they involve the taking of human life, some killings possess qualities that differentiate them in the eyes of the social audience from those killings that are considered illegitimate. While the act remains the same, the social definitions interpreting the event may vary. As Friedman (1993: 173) writes, "In part, violence is a matter of definition, or at least of perspective . . . Every society defines a sphere of legitimate private violence." In other words, the legitimacy of any particular killing lies not in any intrinsic quality of the act itself but rather in its definition. Evidence indicates that often perpetrators of violence see themselves as being justified in their actions (See for example Katz 1988) because they often define the criminal act as a legitimate response to some behavioral or ethical breach on the part of their victim. In this sense, their criminal acts are defined as a form of social control by the offender (Black 1983), and this perception of the crime as a form of self help serves to legitimize the crime to the offender and perhaps to others (Kennedy 1988; Skogan 1984). More specifically, in regards to homicide, Katz (1988:16) has argued that killers typically see themselves as acting for moralistic reasons. He suggests "violence erupts in situations that put at stake what the people involved momentarily regard as dimensions of the eternal Good." In other words, individuals act violently in order to protect something they value such as their reputation or honor. These perceptions and definitions as to the morality of the killing provide the rationalization for approval rather than condemnation and involve the imputation of meaning to action in a inherently social, definitional process. Most killings occur in social settings complete with an audience that may play a significant role in the violent event (Luckenbill 1977; Miethe and Meier 1994; Sacco and Kennedy 1996). The audience may consist of first or second hand witnesses such as community members, police officers, media commentators, and others. Accordingly, the definitional process is a subjective one, influenced by the definitional interplay between perpetrators, victims, and audience. Killing is therefore an example of social action in that it involves the social construction of meaning. As Weber (1947: 88 ) suggested, "Action is social insofar as, by virtue of the subjective meaning attached to it by the acting individual (or individuals), it takes account of the behavior of others and is thereby oriented in its course."

The labeling perspective is helpful in understanding the social nature of killing since it highlights the subjective nature of definitions. Contending that actions in and of themselves are not inherently deviant, labeling theorists argue that it is the application of stigmatizing labels to the act and actor that define an act as deviant, or conversely, the application of legitimizing labels that define an act as acceptable and normative. This is clearly the case with killing. As Pfohl (1994: 346) asserts:

Some types of killing are categorized as homicide. Others are not. What differs is not the behavior but the manner in which reactions to that behavior are socially organized....The form and content of what is seen as homicide thus varies with social context and circumstance 
Labeling theory, therefore, suggests that it is the definitional process that is crucial to shaping understanding and perception toward individual acts of killing.

Similarly, some have argued that many of these social definitions and perceptions as to the legitimacy or illegitimacy of killing are contingent upon cultural or subcultural context. Wolfgang and Ferracuti's (1967a) work is one of the earliest examples of this school of thought. Asserting that among certain groups in society there exists a subcultural value system that condones, expects, and even encourages acts of violence to resolve interpersonal conflict. Members of these groups more often perceive and define individual and group acts of violence as legitimate. As Wolfgang (1958: 188189) states:

Quick resort to physical combat as a measure of daring, courage, or defense of status appears to be a cultural expectation...When such a culture norm response is elicited from an individual engaged in social interplay with others who harbor the same response mechanism, physical assaults, altercations, and violent domestic quarrels that result in homicide are likely to be relatively common.

Some scholars have utilized these ideas to explain the South's higher rates of homicide and violence (Doerner 1978; Erlanger 1975; Gastil 1971; Hackney 1969; Huff-Corzine, Corzine, and Moore 1986; Messner 1983a; Messner 1983b; Nisbet and Cohen 1996; Wyatt-Brown 1982). Arguing that because of the South's violent history, the legacy of slavery and the Civil war, a southern culture has developed that encourages violence to protect property, person, and honor. A few scholars have focused specifically on Appalachia (Jones 1948; Montell 1986; Tunnell 1995), while others have examined cultural values among the poor (Cohen 1955; Miller 1958), Latinos (Bourgois 1996; Davidson 1974), and African-Americans (Anderson 1999; Butterfield 1995; Courtwright 1996; Oliver 1994). All, however, assert that among specific subcultural groups there exist normative value systems that serve to legitimate acts of violence and killing in various situations. Some theorists have argued that American culture in general, not just specific subcultures, tolerates and encourages the use of violence in many social interactions and settings (Brown 1975; Brown 1989; Elias 1997; Slotkin 1973;
Slotkin 1985; Slotkin 1992; Toplin 1994). As Brown (1991: 156) writes:

A second issue is ... the extent to which violence is not merely opposed to but actually a part of our value system or, put another way, that there are elements (often unacknowledged) in our value system which encourage and sustain violence. Indeed, there is a sort of underground matrix of American values that, although lacking the approval of opinion leaders and citizens in their better moments, has frequently guided Americans in their behavior: a sub rosa cluster of values that have provided sanction for actions ordinarily considered shameful and wrong - in short, sanction for violence.

Similarly, Wolfgang and Ferracuti (1967b: 277) contend, "that a whole culture may accept the violence value, demand or encourage adherence to it, and penalize deviation." While not without their critics (See for example Blau and Blau 1982; Waller 1988) these arguments are suggestive of the role that cultural values and definitions play in the production of violence and homicide.

In contrast to the labeling and subculture of violence arguments, conflict theorists examine the role of power inequalities in the definitional process and perceive crime as a political definition imposed by those who hold political, economic, and/or social power (Quinney 1970; Turk 1977), arguing that the powerless in society have a greater likelihood of having their actions defined as criminal when those actions are perceived to be a threat to those groups who possess greater power (Gordon 1973; Quinney 1970; Spitzer 1975), or because they lack the means to resist the application of law (Turk 1969). Conversely, those with power are unlikely to define their own actions as criminal, or as Lynch and Groves (1989:40) write, "The point is that .. crime, is a label applied by the powerful to the behavior of the powerless. That does not mean, however, that the powerful are not involved in . . . crime; it merely means that their power allows them to manipulate and hence escape negative labels." Similarly, conflict-based theories would argue that whether acts are perceived as legitimate or illegitimate is largely the product of those with political, social, and economic dominance. It is their access to the resources and means necessary to control the narratives, representations and laws that 
delegitimize some acts while comparable acts escape a similar fate. While it is essentially true that perceptions of legitimacy may indeed be the purview of the governed, it is clear that the powerful invest considerable time, energy and resources to ensure that distinctions between legitimacy and illegitimacy are consistent with their own interests. In short, these arguments illustrate that normative killings may be legitimated on the basis of relative power relationships since those with power are usually more successful in legitimating their actions.

Common to these perspectives is the recognition that the definitional process is vital in legitimating or illegitimating killing. The killer and the social audience must construct the killing within an understandable framework of meaning. As Turpin and Kurtz (1997: 3) write, "Public discourse on an issue, including debate about violence, revolves around a constellation of images and symbols....Conceptual frames establish boundaries around a set of issues and define how we process information, evaluate interpretive theories, and formulate policies." How the social audience perceives the killing, how they react to it, are all shaped by their understanding of the act. Their understanding is contingent upon a multitude of factors, such as the actors involved, the perceived motivations and justifications or lack thereof, and the social context and circumstances. Killing can therefore be perceived as problematic since meaning needs to be constructed in order to understand it. It is also problematic in the sense that it constitutes behavior outside of the ordinary realm of human interaction. Even though we have relatively high rates of lethal violence in this country, it is still not an everyday "normal" experience for most. Stokes and Hewitt (1976: 842) suggest that:

In the endless flow of situations that constitute experience, much happens that can be viewed only as problematic from the standpoint of participants. Interaction is disrupted, identities are threatened, meanings are unclear, situations seem disorderly, people have intentions that run counter to others' wishes, seemingly inexplicable events take place, people do not know what is happening to them, and the list could be extended almost indefinitely.

Killing certainly meets the criteria for being problematic, and for it to be defined as legitimate it needs to be presented in such a way that it becomes unproblematic or at least less problematic, or to borrow Stokes and Hewitt's (1976: 843) term, it needs to be "Aligned." As they explain:

problematic situations often involve misalignment between the actual or intended acts of participants and cultural ideals, expectations, beliefs, knowledge, and the like. "Alignment" in this sense has to do with perceived discrepancies between what is actually taking place in a given situation and what is thought to be typical, normatively expected, probable, desirable or, in other respects, more in accord with what is culturally normal.

This alignment might involve utilizing disclaimers (Hewitt and Stokes 1975), accounts (Scott and Lyman 1968), quasi-theories (Hall and Hewitt 1970; Hewitt and Hall 1973), and/or vocabularies of motives (Cressey 1954; Mills 1940). In all cases, however, they involve the reference to ideas, symbols, mythologies, concepts, and images that the individual and the group can understand and accept as relevant and valid. In trying to understand acts of lethal violence, people do not rely upon purely individualistic arguments to construct meaning; instead, they typically refer to larger, often culturally created, images and ideas. In other words, the meanings of individual acts of killing are thematically organized along patterned lines that often reflect socially constructed symbols and messages. When an individual defends his or her violence to others and to themselves, they do so by referring to ideas and justifications that are derived from the larger cultural context. This construction of meaning along socially recognizable themes affects people's perceptions and definitions as to the perceived legitimacy of their actions, even if it involves killing. As such, normative killings may be successfully linked to specific concepts of legitimacy that embody a variety of cultural themes. These themes usually replicate existing social arrangements or relationships and must be present for a killing to be perceived as normative.

\section{VOCABULARIES OF LEGITIMATION}

We have identified what we call "vocabularies of legitimation" that are common to normative killings and have labeled them "differential life value," "conservatism," and "justification." These concepts must be called into play if a killing is to be defined as legitimate. It is these vocabularies of legitimation that 
serve to link acts of violence with perceptions of legitimation. They act as mechanisms that transform perceptions of lethal violence from something bad into something that is less reprehensible and at times even legitimate. In other words, these vocabularies of legitimation allow otherwise problematic behavior to be aligned so that it becomes non-problematic. If they are not present in a particular killing, the two distinct and separate realms of killing and legitimacy cannot be linked, and consequently the killing remains illegitimate. Before illustrating the applicability of these metaphors to specific types of normative killings, a brief review of their specific characteristics is necessary.

\section{Differential Life Value}

While it may be a truism that in the western tradition all human life is sacred and special, it is also true that some life is considered more sacred than others. Life value is not an objective asset that exists independent of the social audience. It is an ascribed value and as such is contingent upon a variety of factors including race, gender and ethnicity, as well as stereotyped imagery, traditional perceptions, economic, political, and social prestige and power. In other words, it is subjective and mutable because individuals, communities, and societies continuously make judgments about the relative value of others on the basis of ascribed characteristics. These judgments are spatially and temporally located in that they vary over time and place depending upon a number of variables.

In the contemporary U.S. the assignation of differential worth to specific individuals and groups appears to exist. Much evidence indicates that the police, for example, exercise their discretion selectively based in large part on their judgment as to the social value of the people and groups they deal with. In other words, police are more willing to arrest and use force against those who are seen as having a lower life value such as non-whites, those from disadvantaged neighborhoods, and teenagers (Black 1980; Brooks 2010; Tapia, 2010; Terrill and Reisig 2003). Evidence on discrimination in the administration and application of justice indicates that various minority groups are discriminated against in a variety of contexts. For example, many studies have found that AfricanAmericans are more likely to be detained, arrested, subjected to use of force, tried, found guilty, sentenced to longer terms, and serve more of their sentences than whites (D'Allessio and Stolzenberg 1993; Daly and Tonry 1997; Free 1996; Kleck 1981; Mann 1993; Petersilia 1983; Tapia 2010; The Sentencing Project
2005). This is also often true for other minority groups such as Latinos (LaFree 1985; Petersilia 1983; The Sentencing Project 2005; Unnever 1982; Unnever and Hembroff 1988; Zatz 1984), and American Indians (Alvarez and Bachman 1997; Bachman, Alvarez, and Perkins 1996; Bynum and Paternoster 1984; Droske, 2008; Hall and Simkus 1975; Swift and Bickel 1974; Williams 1979). On one level, the causes of this differential treatment have been defined in terms of racism, classism, and cultural stereotyping. All, however, presuppose a lower value placed upon those discriminated against. Hawkins (1986) specifically argues that the historical treatment of AfricanAmericans in the U.S. has resulted in a devalued life value relative to whites. Thus, when whites or AfricanAmericans murder African-Americans they tend not to be as severely punished. When African-Americans murder whites, however, they are punished more severely and are more likely to receive the death penalty in states that have retained this penalty (Levinson, Smith and Young 2013; Lynch and Haney 2011). Decades ago, Black (1976) made the same argument when he asserted that law is stratified because it is applied differently depending upon the hierarchical social position of the person or persons to whom it is being applied. For him, the relative positioning of the perpetrator vis a vis the victim is crucial because depending upon a person or group's relative position in the stratification system of that society, the value that is given to their life or lives affects how they are legally treated.

The media assists in the creation of this image of lesser value through descriptions of offenders and offenses. For example, in reporting the police shooting of a man in his own kitchen that authorities termed "totally justified," it was reported that the victim had a criminal past, something which was clearly inconsequential to the interpretation of the sequence of events leading to the shooting. The media account described the deceased as having been just released from jail after police had arrested him on suspicion of driving on a suspended license. It was also reported that he had started smoking marijuana at 11 and drinking alcohol at 14 , according to court records. Additional information was provided that he had first entered the justice system as a teen and was imprisoned for armed robbery, forgery and theft in the late $80 \mathrm{~s}$ and early $90 \mathrm{~s}$, and since that time had amassed a series of minor offenses, from failure to appear in court to traffic violations (Arizona Republic, March $\left.8^{\text {th }} 1999: B-1\right)$. All of this information, though 
irrelevant to the case at hand, served to devalue the life of the shooting victim. By portraying the deceased as a career criminal and a drug and alcohol user, the paper essentially diminished the worth of the man, while on the other hand, descriptions of the officer seem to foster support and value. The shooter was reported to be "an experienced officer who is a very good communicator. His file with police shows no major problems" (Arizona Republic, March $8^{\text {th }}$ 1999:B-1). Another officer involved in a shooting was described as, "a decorated cop who once crawled into a burning building to rescue a man. A year later, the officer was credited with reviving and saving the life of a one year old who suffered a seizure" (Arizona Republic, March $\left.19^{\text {th }} 1999: B-1\right)$. In another example, authorities went so far as to dig up the past prison disciplinary history on one victim of a police shooting, feeding the media with information like "Williams had been released from prison after serving time for a weapons violation. He racked up more than 70 rules violations, ranging from threatening staff members and others to possession of manufactured weapons" (Arizona Republic, March $19^{\text {th }}$ 1999:B-1)

In the case of Trayvon Martin we see similar attempts on the part of some in the media to cast him in a more sinister light. For example, Geraldo Rivera said because Trayvon Martin was dressed in "thug wear," (which apparently refers to wearing hooded sweatshirt while out in the rain) he was to blame for his own demise (The Huffington Post, 2012). A website for conservative pundit Glen Beck hinted that Martin may have been a kidnapper, murder and arsonist (The Blaze, 2012). While these are clearly not unbiased accounts, they again show how attempts to legitimate the killing are often carried out by questioning the character of the victim, in this case by exploiting racial stereotypes, or by trying to reduce the value of that life in the eyes of the social audience. To be sure the same efforts are made on the part of those who attempt to delegitimize a particular killing by highlighting the fallible nature of the perpetrator or by highlighting the virtuous qualities of the victim.

Such portrayals serve to increase the relative life value of the killer vis-à-vis the victim. It is irrelevant if the shootings were in fact justified or not, rather, the point is that these portrayals serve to place the relative and subjective worth of the individuals in sharp contrast.

To sum, normative killings are perpetrated against those whose lives are valued less in relation to the perpetrator and the wider social audience that either condemns or condones (Mills, 2007). The killing of a person whose life has a great deal of ascribed social value is usually not going to be legitimated, especially if the killer is from a group whose life is valued less than the victim's. However, the more valued a person is, especially in relation to a less valued victim, the more likely that these vocabularies can successfully be called into play and thus legitimize the violence.

\section{Conservatism and Justification}

The nature of normative killing is invariably conservative in that it does not challenge traditional power structures and arrangements. Indeed, normative killings are those that preserve, protect, and maintain existing economic, political, and social arrangements. When people kill to protect property, for entrenched ideology, political capital, even privilege, the killing is more likely to be defended and legitimated.

If perpetrated by agents of the community or state, the killing is by definition conservative, as this type of killing is usually committed with explicit and official legal approval. Law enforcement officials who use force typically do so in order to defend life and property as prescribed in law and as a society we tend to be very tolerant of this type of violence. As Kahn (1972: 164) pointed out, "American men are prepared to justify very substantial amounts of force and injury by the police for the sake of social control, and there is no requirement that the precipitating events have initiated personal violence. " Conversely, Kahn found very little support for violence as an instrument for social change. Richard Maxwell Brown (1989: 23-24) echoes this sentiment when he writes:

A salient fact of American violence is that, time and again, it has been the instrument not merely of the criminal and disorderly but of the most upright and honorable...The threat to the structure of society mounted by the criminal and the disorderly has been met energetically by the official and unofficial violence of the forces of law and order. Often perceiving a grave menace to social stability in the unsettled conditions of frontier life and racial, ethnic, urban, and industrial unrest solid citizens rallied to the cause of community order. They did this indirectly by granting to the police and other duly constituted agents of the community the 
power to commit violence to preserve order. Not confining themselves to passive approval of police action, these upright citizens revealed their deep commitment to community order by their own violent participation in lynch mobs, vigilante movements, and other extralegal bodies. Violence thus employed has been socially conservative. Whether employed legally or extralegally, it has been used to support the cohesive three-tiered structure of the American community with its upper, middle, and lower classes and its underlying social values of law and order and the sanctity of property.

This violence, as Brown notes, whether official or unofficial, must be perceived to be in the service of traditional and established values and principles if it is to be accepted. Killing in the service of social, political, and economic change is rarely, if ever, legitimated.

Closely linked and intertwined with the language of Conservatism is that of Justification which we shall differentiate for explicatory purposes. It can be argued that killings are only legitimated when they can be successfully linked to higher, socially approved goals. Typically, as discussed above, these socially approved of goals are conservative in nature. Killing is rarely legitimated if it occurs for individualistic, selfish, ignoble, or petty purposes. As Toch (1993: 200) noted, "Good violence is seen as good because it is instrumental in a good cause." An example of this would be when police shoot a suspect to prevent him from killing others in an attempt to avoid arrest. Also, in a society such as ours that emphasizes the private acquisition of commodities and wealth, killing to protect ownership is perceived by some as normative and is at times even protected by law. Currently, thirty-one states have expanded self-defense laws, a number of which allow the use of force and even deadly force in the defense of property such as preventing a burglary (CNN.com 2014). Killing that is linked with noble sentiment and ideology is also a powerful justification for legitimacy. Indeed, Brown (1989) argues that this nation was founded on normative killing during the Revolutionary war, and that this has profoundly shaped the notion that killing, when done for noble reasons, is a valuable and acceptable social tool. Subcultural theorists have long pointed out that, to members of some subcultures, violence and killing are justified if perpetrated in response to an insult, in order to protect honor, or for reasons of respect (Anderson 1999; Bourgois 1996; Butterfield 1995; Wyatt-Brown 1982).

The Trayvon Martin case provides an illustration of this interconnection between conservatism and justification. In the aftermath of the shooting many defended the actions of George Zimmerman as an attempt to control crime and prevent disorder. Neighbors noted, and the media faithfully reported, that there had been a rash of burglaries in the neighborhood, supposedly, though unsubstantiated, committed by young black men in the year or so prior to the confrontation. Moreover, Zimmerman, himself claims he was simply defending himself. Either way, it is clear Zimmerman and others attempted to legitimate the lethal violence by defining it as a justified act meant to protect against a threat to the social order as well as to two highly esteemed American values, namely private property and life.

The vocabularies of justification and conservatism are even more apparent by more closely examining killings that are not only perceived as legitimate but are legal as well.

\section{Justifiable Homicide}

Justifiable homicides are those killings that are legally accepted as permissible. Technically, they have been defined as non-culpable, intentional killings. At present in the U. S., there are two types of legally justifiable homicides: those committed by citizens and those perpetrated by law enforcement officers in the course of duty. Generally speaking, police officers and civilians are legally permitted to use deadly force in order to protect themselves or third parties from serious physical harm or death, and in some places to protect premises and property. Police may also use deadly force to prevent the commission of certain crimes and to prevent the escape of dangerous felons (Matulia 1985).

While subject to specific legal criteria, justifiability is contingent, in part, on subjective definitions that are consistent with vocabularies of legitimation. For example, killings by police are almost normative by default since most police shootings are routinely defined as legitimate and warranted (Fyfe 1979; Fyfe 1988; Geller and Karales 1981; LaGrange 1998; Sherman 1983; Uelman 1973).

Obviously, many find it problematic to question violence, even lethal violence, when perpetrated by law 
enforcement officials. Among large segments of the population, the perception apparently is that police kill only to protect the established order. They defend life and property, stop crime, and uphold laws. In fact, historically many citizens did not even define police shootings as an act of violence. In a 1969 survey, 57 percent of the sample did not interpret police shooting looters as an act of violence (Blumenthal et al. 1972). Evidently, there are too many negative connotations associated with the term violence for some people to relate that term to law enforcement officials who use lethal force.

Additionally, when police officers shoot, they shoot people who are assumed to be guilty of crime. These victims are typically perceived as being dangerous and violent perpetrators and offenders, pejorative definitions that carry dehumanizing connotations and effectively lowers their status. In other words, the victims of police shootings are defined as people who deserved what happened to them and this impression is fostered and reinforced by the labels with which they are identified such as "career criminals" or "armed and dangerous." Another characteristic of justifiable homicide is that not all groups are equally at risk. Research seems to indicate that African-Americans are disproportionately the victims of police shootings relative to their size in the population (Alvarez 1992; Binder 1982; Blumberg 1989; Fyfe 1981; Fyfe 1982; Geller 1982; Geller and Karales 1981; Harring et al. 1977; Lee 2004; Meyer 1980;; Robin 1963; Takagi 1974). Geller and Scott (1991: 453) write, "The most common type of incident in which police and civilians shoot one another in urban America involves an onduty, uniformed, white, male officer and an armed black, male civilian between the ages of 17 and 30 in a public location within a high-crime precinct at night in connection with a suspected armed robbery or a "man with a gun" call." While some have suggested that this disparity is exclusively the result of greater AfricanAmerican involvement in felonious crimes, others have argued that it is instead the result of systematic racism among police officers, or as Takagi (1974:27) succinctly asserts, "Police have one trigger finger for whites and another for blacks." Given the amount of evidence indicating that at different stages, and in different locations, significant discrimination against African-Americans and other minority groups exists (Conley 1994; D'Allessio and Stolzenberg 1993; Kleck 1981; Mann 1993; Petersilia 1983; Pope and Feyerheim 1990; Walker, Spohn, and DeLone 2000), it seems reasonable to suppose that at least some of the disproportionate shooting of African-Americans by police officers is caused by racist attitudes. This pattern is also consistent with Hawkins' (1986) thesis that because of the historic experiences of AfricanAmericans, their lives have been devalued relative to white life. Hence the shooting of them by police officers is more likely to be judged legitimate. In short, the patterns exhibited by justifiable homicides supports our argument concerning the importance of our three vocabularies of legitimation. The historical use of lynching, as well as the contemporary exercise of the death penalty, similarly reveals the importance of devalued life status, justification, and conservatism.

\section{Lynching}

While not a current form of normative killing, lynching does offer a historic illustration of the vocabularies crucial in legitimating killing. Born during the Revolutionary war, lynching first came into widespread use during the turbulent post-civil war years in the American south and throughout the western frontier, flaring up periodically until the early 1950s. Lynching commonly refers to the killing, whipping, and general brutalization and terrorization committed by self-appointed guardians of the social order. While Lynching began as an extra-legal means to punish alleged criminals and loyalists to the crown during the Revolutionary War, after the abolition of slavery it evolved into a method to ensure recently freed slaves did not challenge the authority and power of the white ruling class, and that those who did so were made to pay for their temerity. In this sense, the actions of the lynch mobs were conservative and justified in the sense that they were protecting traditional privileges enjoyed by the white population. In short, lynching became a tool used to ensure the subservience and obedience of the African-American population. Even though the south had lost the war, white southerners continued the struggle to preserve their privileges and deeply resented the loss of their way of life. Because the legal structure preserving their feudalistic way of life had been stripped away by the victorious North, threatened white southerners turned to lynching as a method for confirming their status.

Because the rights of the African-Americans were protected by newly mandated laws as well as the recent thirteenth amendment to the constitution, the actions of the lynch mobs were clearly illegal. In terms of their social acceptability, however, their actions were just as clearly in line with the thinking of the white populace. Lynchings were invariably committed by 
groups of citizens sympathetic to the cause of maintaining white supremacy. As such the members of lynch mobs or groups often were prominent citizens and leaders within the white community and their extralegal activities were often aided and abetted by many others within the white community. Police officers turned the other way, allowed prisoners to be lynched, and refused to investigate the deaths perpetrated by these groups. The white population believed lynching to be a righteous and necessary tool of maintaining social order (Inverarity 1976; Skolnick and Fyfe 1993). As Inverarity (1976:264) summarizes, "..lynching in Louisiana unequivocally involved popular participation and legitimation." This support was not limited to Louisiana but was present wherever lynchings occurred.

Most scholars recognize that the use of lynching in the American South was a means to a specific end. As Tolnay, Beck, \& Massey (1989: 606) observe, "These killings were not random but rather had an instrumental role in southern society.... That lynchings were a mechanism for maintaining white supremacy in the social and economic institutions of southern society is clear..." Increases in lynchings invariably followed social unrest and times of dislocation. O'Brien (1989: 232). states, "Long a means of "keeping blacks in their place" - a place of economic dependence, political impotence, and social and cultural subservience organized racial violence especially scarred the South during periods of economic and social dislocation, i.e., during times when change appeared most likely. These included the years immediately following the Civil War and World War I and the depression eras of the 1890s and the 1930s." In short, whenever, African Americans attempted to change their devalued status relative to whites, they were subjected to these harsh and repressive means of control. It should also be pointed out that African Americans were not the only victims of lynchings. At different points in time and in different places, Cubans, labor organizers, Mexicans, and Native Americans were the victims of lynch law. Typically, the victims were seen as members of an inferior group who were perceived to be challenging the established social order and values.

\section{Death Penalty}

The use of death as a means of punishment is one of the oldest and most extreme methods of sanctioning wrongdoers in the U.S. With the exception of a death penalty moratorium during most of the 1970s, the U.S. has consistently employed execution as a form of punishment.
In one sense, the death penalty is the supreme expression of the power inherent within the state. The state has the absolute power to take away the life of any citizen that is deemed to deserve that singular punishment. As Phillips (1987: 362) writes:

With an execution, the defendant's fate has supposedly been determined by a jury proceeding under the watchful eyes of an impartial trial judge.....The sentence, when finally administered, is carried out by legitimate authorities performing their sworn duty. The "law" itself is not threatened by an execution. If anything, its power is enhanced through the potent symbolic messages transmitted by an official killing. An execution is an awesome exhibition of the law's true power: its ability to take the most precious of commodities -- life.

As such, the death penalty is clearly a tool of conservative social control, and, as the evidence indicates, it frequently is applied discriminatorily in patterns that act to maintain status inequalities in American society.

In the United States, the likelihood of a criminal receiving a death sentence and of being executed has as much to do with the issue of race as it does with ostensibly more relevant issues such as prior criminal record and the heinousness of the offense. The discriminatory patterns evidence systematic devaluation of African-American life and a corresponding higher worth placed on white life. As previously mentioned, African-Americans who kill whites are more likely to get the death penalty than whites who kill whites, African-Americans who kill African- Americans, and whites who kill AfricanAmericans (Arkin 1980; Keil and Vito 1989; Kleck 1981; Radelet 1981; Radelet and Pierce 1985; Zeisel 1981). Since the age of slavery, African-Americans have consistently been devalued in this society. Relegated to the lowest rungs of the socio-economic ladder, they have struggled constantly to overcome political, social, and economic discrimination, racism, and prejudice. Correspondingly, African-Americans who kill other African-Americans are not perceived as having committed a serious offense. In the past, when the death penalty was applied to rape cases, the evidence shows that African-Americans who were found guilty of raping white females were 18 times more likely to receive a death sentence than any other racial combination (Wolfgang and Riedel 1973). 
Executioners are official agents of the state and thus symbolically act out our collective will and desire. As such, their lethal actions arise not out of personal belief, although those may coincide, but out of obligation and duty. The ostensible justifications for these executions are couched in sentiments of deterrence, incapacitation, and retribution that provide a rationale for legitimacy, above and beyond legality. To sum, then, the death penalty in the U.S. illustrates the three concepts of justification, conservatism, and differential life value.

\section{Research and Policy}

This paper maintains that the concept of normative violence deserves greater attention for a variety of reasons. First, while there is variation in fear of crime across such demographic variables as gender and income, overall, Americans in general are seemingly still experiencing relatively high levels of fear of crime even during times of stabilizing crime rates. For example, a 2010 Gallup poll found that almost 4 of 10 (37\%) Americans indicate being fearful of walking alone at night within a mile of their home (Gallup 2010). As David Garland (2001:152) notes, crime has become a salient feature for many Americans. While once primarily confined to fleeting and specific contextual experiences, fear of crime has become a "social fact" for many who now organize their daily lives around it. Moreover, it also appears that the American public is particularly fearful of violent crime. Many have come to believe violence is an increasing threat even in the context of today's stable violent crime rates. One possible explanation for this may be that normative violence also contributes to the perception that violent crime is widespread. That is, because many people may fail to distinguish between illegitimate and legitimate forms of violence, fear may be exacerbated when one or both are garnering widespread public attention. For example, media coverage of such events as wars, capital executions, and police shootings may simply create the image that violence is ever-present, thereby intensifying individual fear.

Moreover, as individuals become more fearful, they may also become more susceptible to "vocabularies of punitive motive" (Melossi 1985). In other words, personal insecurity interacts with media representations and political rhetoric to produce public support (or at least a lack of opposition) for and the adoption of increasingly more expressive and punitive social control measures. Empirical research as to the influence of representations of normative violence can contribute to a better understanding of the factors that help shape public sentiment concerning fear of crime and support for punitive sanctions.

More importantly, however, we believe the study of normative violence can provide expanded insight into violence and killing in general. As mentioned earlier, some evidence suggests there is a connection between normative forms of violence and illegitimate violence and killing as in the hypothesized "brutalization effect" of capital punishment and in the sometimes fatal effects of the "subculture of violence" that has been associated with the South. These examples suggests that violence that is routinely normalized may produce the unintended consequence of increasing illegal violence and killing by sending a confusing message concerning the acceptability of violence as a means of conflict resolution. In fact, Huesmann and Guerra (1997) demonstrated that children who believe that aggression is an appropriate response are more aggressive relative to those who believe it is inappropriate.

If certain types of violence are legitimated, either explicitly or implicitly, we send a conflicting message about right and wrong. This type of legitimation blurs the moral boundaries of individuals and societies. This is readily seen in times of war during the rare instances when soldiers engage in violent, criminal acts. In 2006, several American soldiers in Iraq were arrested and charged for rape of a teenage Iraqi girl, who they later murdered along with her family (The New York Times 2008). One explanation for such atrocities is that moral compasses go awry during times of war. Violence and killing are mandated and expected in many instances during wartime. When legitimate killing becomes an important facet of one's everyday life and identity, it can become difficult to distinguish between which types of killing are acceptable and which are not. This may be especially true for children or the mentally ill who may lack the rationality to make sense of the distinction between so-called "legitimate" and non-legitimate killing. The result is that they lack clear and proper guidelines for making decisions in ordinary situations. A slight offense or provocation is thus, at times, responded to with fatal consequences.

Research, therefore, must continue to address three interrelated aspects of the influence of normative killings on illegal (or non-normative) violence. The first aspect involves the social construction of violence. In other words, how do politicians, the media, interest groups and others use discourse and certain imagery 
to justify or normalize some forms of violence while vilifying others, and to what extent do such representations reinforce the interests of those who make such claims.

However, such constructions are only effective if they resonate with the public. The second aspect of research, therefore, should focus on how social audiences react to violent acts and to what extent these reactions are conditioned by those who tend to have considerable influence over how definitions of violent acts are constructed. For example, what are the specific factors or characteristics of some forms of violence that make them more socially acceptable than others and in what ways are these factors associated with the discourse of legitimation (i.e., differential life value, conservatism and justification)? What is it, in other words, that allows us to accept certain forms of violence as legitimate? We have shown how discourse that is presented through the media or official reports can contribute to the perception that some lives are simply worth less than others, but research is needed to demonstrate how and in what ways these characterizations resonate with the public and help shape public reaction (or "non-reaction") to certain forms of killing. Other pertinent factors might include the official status or role of the perpetrator, whether the violence was seen as a response to some particularly menacing threat, or whether the violence was perceived as being initiated in defense of established and embraced principles and values.

Finally, research should examine of how individuals process these wider societal reactions. Namely, how do individuals use societal cues as to the acceptability of some forms of violence to determine their own particular course of action in potentially violent situations? Since, clearly, most individuals do not participate in criminal forms of violence such as murder, rape and robbery, one important aspect of this research is to identify the factors that interact with the normalization of violence to produce illegal, violent behavior among some individuals. For example, it is possible that those who already have aggressive personalities or a predisposition to violence may be more prone to use the legitimation of some forms of violence as a stimulus or justification for their own illegal behavior.

The research outlined above can provide a better understanding of our attitudes toward normative forms of violence and the potential consequences of such sentiments. It also would ideally help inform what types of interventions may work to reduce violence in our society. For example, once these connections are more empirically established, they can provide the impetus for implementing a series of strategies aimed at reducing the situations and contexts in which violence is defined and reacted to as acceptable.

If the legitimation of certain forms of killing is learned in interaction with a variety of social actors and groups, and all cultural values are, then it can be unlearned and non-violent dispute and conflict resolution can become increasingly normalized. This requires a change in the way killing is defined or justified by those who kill and in how individuals and wider social audiences react to violence. Specifically, we need to limit the circumstances in which killing is normalized and approved of and expand the contexts in which it is condemned by social audiences. This can only be accomplished by first identifying the ways in which lethal and non-lethal violence are legitimated and then deconstructing such legitimations by enlisting the assistance of a variety of stakeholders. In other words, it is imperative to weaken the distinction between normative and non-normative killings and emphasize that killing is largely illegitimate and ensure that it is only justified in very rare and legally prescribed instances.

For this to occur, it is first necessary to unromanticize all forms violence. Many soldiers, police officers, and individuals who have resorted to lethal force can attest to the fact that there is very little that is romantic about taking another's life, regardless of the circumstances or justifications. Politicians can avoid discourse that legitimates certain forms of violence. One way this may be accomplished is by emphasizing that war, when deemed necessary, is a last and unwanted option. Also, we need to stop referring to crime fighting as "wars," which merely legitimates violent and often deadly responses and which cast the casualties as the unavoidable consequence of protecting societal values and interests. Media can also help by de-emphasizing romantic images of certain forms violence, refusing to reproduce differential life value narratives and critically examining all forms of killing, regardless of purpose or justification. Criminal justice practitioners also must play a role by creating and emphasizing unambiguous policies that clearly limit the use of force, especially deadly force, to very rare and extreme circumstances. Concomitantly, internal and civilian review boards must be more vigilant in determining whether police shootings were in fact justified. Technological advances in and the 
adoption of less than lethal weapons for law enforcement agents would also ideally lead to fewer deaths and consequently fewer instances justifying them. And, finally we should institute a nation-wide moratorium on the death penalty.

We note that the above suggestions for limiting and more precisely defining the circumstances in which violence is approved of will be difficult as it involves both the re-orienting of certain values as well as conscious efforts to change the discourse in which violent acts, both normative and illegitimate, are discussed. The problem is complicated by the fact that there are many who often benefit in a number of ways from such representations. Nevertheless, we believe that these suggestions along with empirical research are a starting point for addressing the potentially unintended consequences of normative violence. The desired effect is that the de-legitimation of most forms of violence will ideally be accompanied by a reduction in non-normative killings; thereby creating a safer society with decreasing levels of citizen fear.

\section{CONCLUSIONS}

Violence, as some have suggested, is as American as apple pie. Yet not all violence is understood and treated the same. While we accept and tolerate certain specific acts of violence, we condemn others. In this article, we have attempted to explore some of the issues surrounding those forms of violence and killings judged to be normative. Specifically, we have identified three connected themes or metaphors that must be perceived for a killing to be defined as legitimate. It is important to recognize that the amount of violence in a society is related to the means by which those individuals and that society can justify those acts of violence to themselves and each other. We must recognize that many individuals who kill do so with the perception that they are defending some valued object, and that if we are to truly make our society safer and less violent, we need to understand the mechanisms that underlay these assumptions.

\section{REFERENCES}

Alvarez, Alex. 1992. "Trends and Patterns of Justifiable Homicide: A Comparative Analysis." Violence and Victims 7:347-357.

Alvarez, Alex and Ronet Bachman. 1996. "American Indians and Sentencing Disparity: An Arizona Test." Journal of Criminal Justice 24:549-561. http://dx.doi.org/10.1016/S0047-2352(96)00039-6

Anderson, Elijah. 1999. Code of the Street: Decency, Violence, and the Moral Life of the Inner City. New York: W. W. Norton and Company.
Archer, Dane, and Rosemary Gartner. 1984. Violence and Crime in Cross-National Perspective. New Haven: Yale University Press.

Archer, Dane and Rosemary Gartner. 1976. "Violent Acts and Violent Times: A Comparative Approach to Postwar Homicide Rates." American Sociological Review 41:937-963. http://dx.doi.org/10.2307/2094796

Archer, Dane, Rosemary Gartner, and M. Beittel. 1983. "Homicide and the Death Penalty: A Cross-National Test of Deterrence Hypothesis." The Journal of Criminal Law and Criminology 3:991-1013.

http://dx.doi.org/10.2307/1143141

Arizona Republic. 1999. "Two Killed by Police Were Felons." March 19, p. B-1. Retrieved July 25, (http://search.proquest.com/ arizonarepublic/docview/237900971/2F733D638FA74CBEP $\mathrm{Q} / 2$ ?accountid=12706)

Arizona Republic. 1999. "Shooting 'Totally Justified' Police Say Phoenix Man Wouldn't Drop Weapons." September 8, p. B-1. Retrieved July 25, (http://search.proquest.com/arizonarepublic/docview/237911403/FE50FFEB67AE4269PQ/3?acco untid=12706)

Arkin, Steven D. 1980. "Discrimination and Arbitrariness in Capital Punishment: An Analysis of Post-Furman Murder Cases in Dade County, Florida, 1973-1976." Stanford Law Review 33:75-101. http://dx.doi.org/10.2307/1228523

Bachman, Ronet, Alex Alvarez, and C. Perkins. 1996. "Discriminatory Imposition of the Law: Does It Affect Sentence Outcomes for American Indians?" Pp. 197-208 in Native Americans, Crime, Law, and Justice, edited by M. Nielsen and R. Silverman. Boulder: Westview Press.

Bailey, William C. 1982. "Capital Punishment and Lethal Assaults Against Police." Criminology 19:608-625. http://dx.doi.org/10.1111/j.1745-9125.1982.tb00441.x

Bailey, William C. and R.D. Peterson. 1994. "Murder, Capitol Punishment, and Deterrence: A Review of the Evidence and an Examination of Police Killings." Journal of Social Issues 50:53-74.

http://dx.doi.org/10.1111/j.1540-4560.1994.tb02410.x

Ball-Rokeach, Sandra J. 1980. "Normative and Deviant Violence from a Conflict Perspective: A Review of the Evidence and an Examination of Police Killings." Social Problems 28:45-61. http://dx.doi.org/10.1525/sp.1980.28.1.03a00040

Binder, Arnold, and Peter Scharf. 1982. "Deadly Force in Law Enforcement." Crime and Delinquency:1-23. http://dx.doi.org/10.1177/001112878202800101

Black, Donald. 1976. The Behavior of Law. New York: Academic Press.

- 1980. The Manners and Customs of the Police. New York: Academic Press.

—. 1983. "Crime as Social Control." American Sociological Review 48:34-45. http://dx.doi.org/10.2307/2095143

Black, Max. 1962. Models and Metaphors: Studies in Language and Philosophy. Ithaca, New York: Cornell University Press.

Blau, Judith R. and Peter M. Blau. 1982. "The Cost of Inequality: Metropolitan Structure and Violent Crime." American Sociological Review 47:114-129. http://dx.doi.org/10.2307/2095046

The Blaze. 2012. URL tawana-brawley-2-0-al-sharpton-sides-withaggressor-in-self-defense-case

Blumberg, Mark. 1989. "Controlling Police Use of Deadly Force." Pp. 469-492 in Critical Issues in Policing, edited by R. G. Dunham and G. P. Alpert. Prospect Heights, Illinois: Waveland Press.

Blumenthal, Monica D., Robert I. Kahn, Frank M. Andrews, and Kendra B. Head. 1972. Justifying Violence. Ann Arbor, Michigan: University of Michigan Press. 
Blumer, Herbet . 1969. Symbolic Interactionism. Englewood Cliffs, NJ: Prentice Hall

Bourgois, Philippe. 1996. In Search of Respect: Selling Crack in EI Barrio. Cambridge: Cambridge University Press.

Bowers, William J. 1984. Legal Homicide. Boston: Northeastern University Press.

Bowers, William J. and G. L. Pierce. 1980. "Arbitrariness and Discrimination under Post-Furman Capital Statutes." Crime and Delinquency 26:563-635. http://dx.doi.org/10.1177/001112878002600409

Brooks, Laure W. 2010. "Police Discretionary Behavior: A Study of Style." Pp. 89-105 in Critical Issues in Policing, edited by R. G. Dunham and G. P. Alpert. Prospect Heights, Illinois: Waveland Press.

Brown, Robert M. 1975. Strain of Violence. New York: Oxford University Press.

—. 1989. "Historical Patterns of Violence." Pp. 23-61 in Violence in America, Protest, Rebellion, Reform, vol. 2, edited by T. R. Gurr. Newbury Park, California: Sage Publications.

—. 1991. No Duty to Retreat: Oxford University Press.

Butler, Judith. 1999. Gender Trouble: Feminism and the Subversion of Identity, $2^{\text {nd }}$ ed. London: Routledge.

Butler, Judith. 2004. Gender Trouble: Feminism and the Subversion of Identity, $2^{\text {nd }}$ ed. London: Routledge.

Butterfield, Fox. 1995. All God's Children: The Bosket Family and the American Tradition of Violence. New York: Alfred A. Knopf.

Bynum, T. and Ray Paternoster. 1984. "Discrimination Revisited: An Exploration of Frontstage and Backstage Criminal Justice Decision Making." Sociology and Social Research 69:90-108.

Caulfield, Susan L. 1991. "The Perpetuation of Violence Through Criminological Theory: The Ideological Role of Subculture Theory." Pp. 228-238 in Criminology as Peacemaking, edited by H. E. Pepinsky and R. Quinney. Bloomington: Indiana University Press.

Chambers, Samuel A. 2007. Normative Violence after 9/11: Rereading the Politics of Gender Trouble. New Political Science 29: 44-60.

http://dx.doi.org/10.1080/07393140601170792

Cheatwood, Darrell. 1993. "Capital Punishment and the Deterrence of Violent Crime in Comparable Counties." Criminal Justice Review 18:165-181. http://dx.doi.org/10.1177/073401689301800202

CNN.com. 2014. Expanded Self-defense Laws. Retrieved August 7, $2014 . \quad$ http://www.cnn.com/interactive/2012/04/us/table. selfdefense.laws/

Cohen, Albert K. 1955. Delinquent Boys: The Culture of the Gang. Glencoe: The Free Press.

Conley, Darlene J. 1994. "Adding Color to a Black and White Picture: Using Qualitative Data to Explain Racial Disproportionality in the Juvenile Justice System." Journal of Research in Crime and Delinquency 31:135-148. http://dx.doi.org/10.1177/0022427894031002003

Courtwright, David T. 1996. Violent Land: Single Men and Social Disorder from the Frontier to the Inner City. Cambridge, Mass.: Harvard University Press.

Cressey, Donald. 1954. "The Differential Association Theory and Compulsive Crime." Journal of Criminal Law and Criminology 45:49-64.

Curriden, Mark 1995. "The Legacy of Lynching." Atlanta Journal and Constitution, January 15, pp. M1.

D'Allessio, Stewart J. and Lisa Stolzenberg. 1993. "Socioeconomic Status and the Sentencing of the Traditional Offender." Journal of Criminal Justice 21:61-77. http://dx.doi.org/10.1016/0047-2352(93)90006-9
Daly, Kathleen and Michael Tonry 1997. Gender, Race and Sentencing. Crime and Justice: Review of Research. 22: 201-252. http://dx.doi.org/10.1086/449263

Davidson, R. Theodore. 1974. Chicano Prisoners: The Key to San Quentin. New York: Holt, Rinehart, and Winston.

Doerner, William G. 1978. "The Deadly World of Johnny Reb: Fact, Foible, or Fantasy?" Pp. 91-98 in Violent Crime: Historical and Contemporary Issues, edited by J. A. Inciardi and A. E. Pottieger. Beverly Hills: Sage.

Droske, Timothy. 2008. Correcting Native American Sentencing Disparity post-Booker. Marquette Law Review 91, issue 3, Article 4.

Elias, Robert. 1997. "A Culture of Violent Solutions." Pp. 117-148 in The Web of Violence: From Interpersonal to Global, edited by J. Turpin and L. R. Kurtz. Urbana, Ilinois: University of Illinois Press.

Erlanger, Howard S. 1975. "Is There a "Subculture of Violence" in the South." Journal of Criminal Law and Criminology 66:483-490. http://dx.doi.org/10.2307/1142888

Flowers, R. Barri 1990. Minorities and Criminality. New York: Praeger.

Free, Marvin D. 1996. African Americans and the Criminal Justice System. New York: Garland.

Friedman, Lawrence M. 1993. Crime and Punishment in American History. New York: Basic Books.

Fyfe, James J. 1979. "Administrative Interventions on Police Shooting Discretion." Journal of Criminal Justice 7:313-335. http://dx.doi.org/10.1016/0047-2352(79)90065-5

-. 1981. "Observations on Police Deadly Force." Crime and Delinquency:376-389.

—. 1982. "Blind Justice: Police Shootings in Memphis." The Journal of Criminal Law and Criminology 73:707-722. http://dx.doi.org/10.2307/1143112

—. 1988. "Police Use of Deadly Force: Research and Reform." Justice Quarterly 5:165-205. http://dx.doi.org/10.1080/07418828800089691

Gallup, George. 2007. The Gallup Poll. www.galluppoll.com/

Garland, David. 2001. The Culture of Control: Crime and Social Order in Contemporary Society. Chicago: University of Chicago Press.

Gartner, Rosemary. 1990. "The Victims of Homicide: A Temporal and Cross-National Comparison." American Sociological Review 55:92-106. http://dx.doi.org/10.2307/2095705

Gastil, Raymond D. 1971. "Homicide and a Regional Culture of Violence." American Sociological Review 36:412-427. http://dx.doi.org/10.2307/2093082

Geller, William A. 1982. "Deadly Force: What We Know." Journal of Police Science and Administration 10:151-177.

Geller, William A. and Kevin J. Karales. 1981. Split Second Decisions: Shootings of and by Chicago Police. Chicago: Chicago Law Enforcement Study Group.

Geller, William A. and Michael S. Scott. 1991. "Deadly Force: What We Know." Pp. 446- 476 in Thinking About Police: Contemporary Readings, edited by C. B. Klockars and S. D. Mastrofski. New York: McGraw Hill.

Gordon, David M. 1973. "Capitalism, Class, and Crime in America." Crime and Delinquency 19:163-186. http://dx.doi.org/10.1177/001112877301900204

Hackney, Sheldon. 1969. "Southern Violence." American Historical Review 74:906-925. http://dx.doi.org/10.2307/1873128

Hall, Edwin and Albert A. Simkus. 1975. "Inequality in the Types of Sentences Received by Native Americans and Whites." Criminology 13:199-222. http://dx.doi.org/10.1111/j.1745-9125.1975.tb00667.x 
Hall, Peter M. and John P. Hewitt. 1970. "The Quasi-Theory of Communication and the Management of Dissent." Social Problems 18:17-27. http://dx.doi.org/10.2307/799877

Harring, Sid, Tony Platt, Richard Speiglman, and Paul Takagi. 1977. "The Management of Police Killings." Crime and Social Justice:34-43.

Hawkins, Darnell F. 1986. "Devalued Lives and Racial Stereotypes: Ideological Barriers to the Prevention of Family Violence Among Blacks." Pp. 189-207 in Violence in the Black Family, edited by R. L. Hampton. Lexington: Lexington Books.

Hewitt, John P. and Peter M. Hall. 1973. "Social Problems, Problematic Situations, and Quasi-Theories." American Sociological Review 33:367-374. http://dx.doi.org/10.2307/2094359

Hewitt, John P. and Randall Stokes. 1975. "Disclaimers." American Sociological Review 40:1-11. http://dx.doi.org/10.2307/2094442

Huesmann, L. Rowell., \& Guerra, Nancy G. 1997. Children's Normative Beliefs About Aggression and Aggressive Behavior. Journal of Personality and Social Psychology, 72 (2), 408-419. http://dx.doi.org/10.1037/0022-3514.72.2.408

Huff-Corzine, Lin, Jay Corzine, and David C. Moore. 1986. "Southern Exposure: Deciphering the South's Influence on Homicide Rates." Social Forces 64:906-924. http://dx.doi.org/10.1093/sf/64.4.906

The Huffington Post. 2012. "Geraldo Rivera Insists He Was Right About Trayvon Martin's Hoodie." July 19, 2012. Retrieved July 25, 2014 (http://www.huffingtonpost.com/tag/geraldorivera-hoodie/)

Inverarity, James M. 1976. "Populism and Lynching in Louisiana, 1889-1896: A Test of Erikson's Theory of the Relationship Between Boundary Crisis and Repressive Justice." American Sociological Review 41:262-280. http://dx.doi.org/10.2307/2094473

Jones, Virgil C. 1948. The Hatfields and the McCoys: Mockingbird Books.

Kahn, Robert L. 1972. "The Justification of Violence: Social Problems and Social Solutions." Journal of Social Issues 28:155-175. http://dx.doi.org/10.1111/j.1540-4560.1972.tb00009.x

Katz, Jack. 1988. Seductions of Crime: Moral and Sensual Attractions in Doing Evil: Basic Books.

Keil, Thomas J. and Gennaro F. Vito. 1989. "Race, Homicide Severity, and Application of the Death Penalty: A Consideration of the Barnett Scale." Criminology 27:511-535. http://dx.doi.org/10.1111/j.1745-9125.1989.tb01044.x

Kennedy, Leslie W. 1988. "Going It Alone: Unreported Crime and Individual Self-Help." Journal of Criminal Justice 16:403-412. http://dx.doi.org/10.1016/0047-2352(88)90065-7

Kleck, Gary. 1981. "Racial Discrimination in Criminal Sentencing: A Critical Evaluation of the Evidence with Additional Evidence on the Death Penalty." American Sociological Review 46:783-805. http://dx.doi.org/10.2307/2095079

LaFree, Gary D. 1985. "Offical Reactions to Hispanic Defendants in the Southwest." Journal of Research in Crime and Delinquency 22:213-237. http://dx.doi.org/10.1177/0022427885022003003

LaGrange, Randy L. 1998. Policing American Society. Chicago: Nelson-Hall Publishers.

Landau, Simha. and Danny Pfefferman. 1988. "A Time Series Analysis of Violent Crime and its Relation to Prolonged States of Warfare." Criminology 26:489-504. http://dx.doi.org/10.1111/j.1745-9125.1988.tb00852.x

Lee, Cynthia, 2004. "But I Thought He Had a Gun: Race and Police Use of Deadly Force." Hastings Race and Poverty Law Journal 2004.
Lempert, Richard. 1983. "The Effect of Executions on Homicides: A New Look in an Old Light." Crime and Delinquency 88-115. http://dx.doi.org/10.1177/001112878302900104

Levinson, Justin, Robert Smith, and Danielle Young. 2013. "Devaluing Death: An Empirical Study of Implicit Racial Bias on Jury-eligible Citizens in Six Death Penalty States." New York University Law Review 89: 513-581.

Luckenbill, David. 1977. "Criminal Homicide as a Situated Transaction." Social Problems 25.

Lynch, Michael J. and W. B. Groves. 1989. A Primer in Radical Criminology. New York: Harrow and Heston.

Lynch, Mona and Haney Craig. 2011. "Looking across the Empathetic Divide: Racialized Decision making on the Capital Jury. Michigan State Law Review vol. 2011 573-607.

Mann, Coramae Richie. 1993. Unequal Justice: A Question of Color. Bloomington: Indiana University Press.

Matulia, Kenneth J. 1985. "A Balance of Forces: Model Deadly Force Policy and Procedure." International Association of Chiefs of Police, Gaithersburg, Maryland.

Mead, George Herbert. 1934. Mind, Self, and Society. Chicago: University Press

Melossi, Dario. 1985. "Punishment and Social Action: Changing Vocabularies of Punitive Motive within a Political Business Cycle." Current Perspectives in Social Theory 6:169-197.

Messner, Steven F. 1983a. "Regional Differences in the Economic Correlates of the Urban Homicide Rate: Some Evidence on the Importance of Cultural Context." Criminology 21:477-488. http://dx.doi.org/10.1111/j.1745-9125.1983.tb00275.x

—. 1983b. "Regional Effects on the Urban Homicide Rate: The Subculture of Violence Revisited." American Journal of Sociology 88:997-1007. http://dx.doi.org/10.1086/227767

Meyer, Maeshall W. 1980. "Police Shootings at Minorities: The Case of Los Angeles." Annals of the American Academy of Political and Social Science 452:98-110. http://dx.doi.org/10.1177/000271628045200110

Miethe, Terence D. and R. F. Meier. 1994. Crime and Its Social Context: Toward an Integrated Theory of Offenders, Victims, and Situations. Albany: State University of New York Press.

Miller, Walter. 1958. "Lower Class Culture as a Generating Milieu of Gang Delinquency." Journal of Social Issues 14:5-19. http://dx.doi.org/10.1111/j.1540-4560.1958.tb01413.x

Mills, C. Wright 1940. "Situated Actions and Vocabularies of Motive." American Sociological Review 5:904-913. http://dx.doi.org/10.2307/2084524

Montell, William L. 1986. Killings: Folk Justice in the Upper South. Lexington: University Press of Kentucky.

New York Times. 2009. "Ex-Soldier Gets Life for Iraq Murders." May 21, A-12. Retrieved July 25, http://www.nytimes.com/ 2009/05/22/us/22soldier.html?_r=0

Nisbet, Richard A. 1969. Social Change and History: Aspects of the Western Theory of Development. London: Oxford University Press.

Nisbet, Richard E. and Dov Cohen. 1996. Culture of Honor: The Psychology of Violence in the South: Westview Press.

O'Brien, Gail W. 1989. "Return to "Normalcy": Organized Racial Violence in the Post-World War II South." Pp. 231-254 in Violence in America: Protest, Rebellion, Reform, vol. 2, edited by T. R. Gurr. Newbury Park, California: Sage Publications.

Oliver, William. 1994. The Violent Social World of Black Men. New York: Lexington Books.

Petersilia, Joan. 1983. Racial Disparities in the Criminal Justice System. Santa Monica: Rand.

Peterson, R. D. and William C. Bailey. 1988. "Murder and Capital Punishment in the Evolving Context of the Post-Furman Era." Social Forces 66:774-807. http://dx.doi.org/10.1093/sf/66.3.774 
—. 1991. "Felony Murder and Capital Punishment: An Examination of the Deterrence Question." Criminology 29:367-395. http://dx.doi.org/10.1111/j.1745-9125.1991.tb01071.x

Pfohl, Stephen. 1994. Images of Deviance and Social Control. New York: McGraw Hill.

Phillips, Charles D. 1987. "Exploring Relations Among Forms of Social Control: The Lynching and Execution of Blacks in North Carolina, 1889-1918." Law and Society Review 21:361-374. http://dx.doi.org/10.2307/3053375

Poe, Danielle. 2008. "Replacing Just War Theory with and Ethics of Sexual Difference." Hypatia 23, Vol. 2 :33-47.

Pope, Carl and Willianm Feyerheim. 1990. "Minority Status and Juvenile Justice Processing: An Assessment of the Research Literature." Criminal Justice Abstracts:327-335, 527-542.

Quinney, Richard. 1970. The Social Reality of Crime. Boston: Little, Brown.

Radelet, Michael L. 1981. "Racial Characteristics and the Imposition of the Death Penalty." American Sociological Review 46:918927. http://dx.doi.org/10.2307/2095088

Radelet, Michael L. and Glenn L. Pierce. 1985. "Race and Prosecutorial Discretion in Homicide Cases." Law and Society Review 19:587-621. http://dx.doi.org/10.2307/3053422

Robin, Gerald 1963. "Justifiable Homicide by Police Officers." Journal of Criminal Law, Criminology, and Police Science 54:225-231. http://dx.doi.org/10.2307/1141171

Saad, Lydia. 2010. Nearly 4 in 10 Americans Still Fear Walking Alone at Night. Gallup-Well Being. www.galluppoll.com/

Sacco, Vincent F. and Leslie W. Kennedy. 1996. The Criminal Event. Belmont: Wadsworth.

Scott, Marvin B. and Stanford M. Lyman. 1968. "Accounts." American Sociological Review 33:46-62. http://dx.doi.org/10.2307/2092239

Shepherd, Joanna M. 2005. "Deterrence versus Brutalization: Capital Punishment's differing Impacts Among States. Michigan Law Review 104:203-55.

Sherman, Lawrence W. 1983. "Reducing Police Gun Use: Critical Events, Administrative Policy and Organizational Change." Pp. 98-125 in Control in the Police Organization, edited by M. Punch. Cambridge, Mass.: MIT Press.

Sidel, Victor W. and Robert C. Wesley. 1996. "Violence as a Public Health Problem: Lessons for Action Against Violence by Health Care Professionals from the Work of the International Physicians Movement for the Prevention of Nuclear War." Social Justice 22:154-170.

Skogan, Wesley G. 1984. "Reporting Crimes to the Police: The Status of World Research." Journal of Research in Crime and Delinquency 21:113-137. http://dx.doi.org/10.1177/0022427884021002003

Skolnick, Jerome H. and James J. Fyfe. 1993. Above the Law: Police and the Excessive Use of Force. New York: The Free Press.

Slotkin, Richard. 1973. Regeneration Through Violence: The Mythology of the American Frontier, 100-1860: Harper Perennial.

- 1985. The Fatal Environment: The Myth of the Frontier in the Age of Industrialization, 1800-1890: Harper Perennial.

- 1992. Gunfighter Nation: The Myth of the Frontier in TwentiethCentury America: Harper Perennial.

Spitzer, Steven. 1975. "Toward a Marxian Theory of Deviance." Social Problems 22:638-651. http://dx.doi.org/10.1525/sp.1975.22.5.03a00080

Stokes, Randall and John P. Hewitt. 1976. "Aligning Actions." American Sociological Review 41:838-849. http://dx.doi.org/10.2307/2094730
Straus, Murray A. 1994. Beating the Devil Out of Them: Corporal Punishment in American Families. New York: Lexington Books.

Swift, B. and G. Bickel. 1974. Comparative Parole Treatment of American Indians and Non-Indians at U.S. Federal Prisons. Washington, D. C.: Bureau of Social Science Research.

Takagi, Paul. 1974. "A Garrison State in a "Democratic" Society." Crime and Social Justice 1:27-33.

Tapia, Michael. 2010. "Untangling Race and Class effects on Juvenile Arrests." Journal of Criminal Justice 38:255-265. http://dx.doi.org/10.1016/j.jcrimjus.2010.03.002

Terrill, Willian and Michael; Reisig 2003. "Neighborhood Context and Police Use of Force." Journal of Research in Crime and Delinquency 40:291-321.

The Sentencing Project. 2005. "Racial Disparity in Sentencing: A Review of the Literature." www.sentenctingporject.org accessed May $7^{\text {th }} 2014$.

Tifft, Larry L. and Lyn. Markham. 1991. "Battering Women and Battering Central Americans: A Peacemaking Synthesis." in Criminology as Peacemaking, edited by H. E. Pepinsky and R. Quinney. Bloomington: Indiana University Press.

Toch, Hans. 1993. "Good Violence and Bad Violence: SelfPresentations of Aggressors Through Accounts and War Stories." Pp. 193-206 in Aggression and Violence: Social Interactionist Perspectives, edited by R. B. Felson and J. T. Tedeschi. Washington, D. C.: American Psychological Association.

Tolnay, Stewart E., E. M. Beck, and James L. Massey. 1989. "Black Lynchings: The Power Threat Hypothesis Revisited." Social Forces 67:605-623. http://dx.doi.org/10.1093/sf/67.3.605

Toplin, Robert B. 1994. "Violence and Culture in the United States." Pp. 237-256 in The Culture of Violence, edited by K. Rupesinghe and R. C. Marcial. Tokyo: United Nations University Press.

Tunnell, Kenneth D. 1995. "A Cultural Approach to Crime and Punishment, Bluegrass Style." Pp. 87-88 in Cultural Criminology, edited by J. Ferrell and C. R. Sanders. Boston: Northeastern University Press.

Turk, Austin T. 1969. Criminality and the Legal Order: Rand McNally.

-. 1977. "Class, Conflict, and Criminology." Sociological Focus 10:209-220.

http://dx.doi.org/10.1080/00380237.1977.10570288

Turpin, Jennifer and Lester R. Kurtz. 1997. "Violence: The Micro/Macro Link." Pp. 1-28 in The Web of Violence: From Interpersonal to Global, edited by J. Turpin and L. R. Kurtz. Urbana: University of Illinois Press.

Uelman, Gerald. 1973. "Varieties of Police Policy: A Study of Police Policy Regarding the Use of Deadly Force in Los Angeles County." Loyola-L.A. Law Review 6:1-61.

Unnever, James. 1982. "Direct and Organization Discrimination in the Sentencing of Drug Offenders." Social Problems 30:212225.

http://dx.doi.org/10.1525/sp.1982.30.2.03a00070

Unnever, James and Larry Hembroff. 1988. "The Prediction of Racial/Ethnic Sentencing Disparities: An Expectation States Approach." Journal of Research in Crime and Delinquency 25:53. http://dx.doi.org/10.1177/0022427888025001004

Walker, Samuel, Cassia Spohn, and Miriam DeLone. 2000. The Color of Justice: Race, Ethnicity, and Crime in America. Belmont: Wadsworth/Thomson Learning.

Waller, Altina L. 1988. Feud: Hatfields, McCoys, and Social Change in Appalachia, 1860-1900. Chapel Hill: University of North Carolina Press.

Weber, Max. 1947. The Theory of Social and Economic Organization. New York: Oxford University Press. 
Williams, Larry E. 1979. "Antecedents of Urban Indian Crime.",, Brigham Young University, Provo, Utah.

Wolfgang, Marvin. 1958. Patterns in Criminal Homicide. Philadelphia: University of Pennsylvania Press.

Wolfgang, Marvin and Franco Ferracuti. 1967a. "The Subculture of Violence.". London: Tavistock.

—. 1967b. "Subculture of Violence-A Socio-Psychological Theory." in Studies in Homicide, edited by M. Wolfgang. New York: Harper and Row.

Wolfgang, Marvin and Marc Riedel. 1973. "Race, Judicial Discretion, and the Death Penalty." The Annals of the American Academy of Political and Social Science 407:119-133. http://dx.doi.org/10.1177/000271627340700110
Wyatt-Brown, Bertram. 1982. Southern Honor: Ethics and Behavior in the Old South. Oxford: Oxford University Press.

Zatz, Marjorie S. 1984. "Race, Ethnicity, and Determinate Sentencing: A New Dimension to an Old Controversy." Criminology 22:147-171.

http://dx.doi.org/10.1111/j.1745-9125.1984.tb00294.x

Zeisel, Hans. 1981. "Race Bias in the Administration of the Death Penalty: The Florida Experience." Harvard Law Review 95:456-468.

http://dx.doi.org/10.2307/1340711

Received on 27-06-2014

Accepted on 14-07-2014

Published on 19-08-2014

DOl: http://dx.doi.org/10.6000/1929-4409.2014.03.19

(ㄷ) 2014 Costelloe and Alvarez; Licensee Lifescience Global.

This is an open access article licensed under the terms of the Creative Commons Attribution Non-Commercial License (http://creativecommons.org/licenses/by-nc/3.0/) which permits unrestricted, non-commercial use, distribution and reproduction in any medium, provided the work is properly cited. 